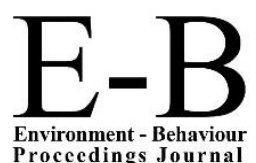

Environment - Behaviour

\section{CSSR 2017}

https://www.amerabra.org; https://fspu.uitm.edu.my/cebs; https://www.emasemasresources.com

$4^{\text {th }}$ International Conference on Science \& Social Research

The Pines, Malacca, Malaysia, 06 -07 December 2017

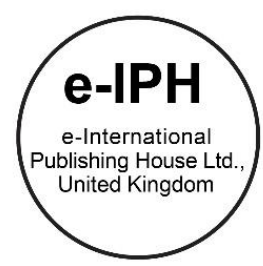

\title{
Reflection in a Mathematics Classroom
}

\section{Teoh Sian Hoon, Parmjit Singh, Cheong Tau Han, Nor Syazwani Mohd Rasid}

\author{
Faculty of Education, \\ Universiti Teknologi MARA, Malaysia \\ teohsian@uitm.edu.my, parmj378@uitm.edu.my, cheongtauhan@uitm.edu.my, norsyazwani@uitm.edu.my \\ Tel: 603-32584926
}

\begin{abstract}
This study was conducted to examine students' reflection in terms of their beliefs and abilities to go through the activities in a problem-solving classroom. Hundred and twenty diploma students were randomly selected from a list of students who had registered in a course called Mathematics Thinking course at a university in Malaysia. The findings revealed that the students encountered difficulties in dealing with the problem-solving activities in the mathematics classroom. Despite giving their best efforts, the students still found challenges in comprehending the context of the issues rendered to them calling for the much indispensable collaboration or peer assistance.
\end{abstract}

Keywords: Written reflection; Mathematics classroom; Problem-solving

eISSN: 2398-4287 @ 2020. The Authors. Published for AMER ABRA cE-Bs by e-International Publishing House, Ltd., UK. This is an open access article under the CC BYNC-ND license (http://creativecommons.org/licenses/by-nc-nd/4.0). Peer-review under responsibility of AMER (Association of Malaysian Environment-Behaviour Researchers), ABRA (Association of Behavioural Researchers on Asians) and cE-Bs (Centre for Environment-Behaviour Studies), Faculty of Architecture, Planning \& Surveying, Universiti Teknologi MARA, Malaysia.

DOI: https://doi.org/10.21834/ebpj.v5iSl1.2289

\subsection{Introduction}

Learning of Mathematics involves complex processes which include conceptual understanding, problem-solving and integrating various Mathematical concepts. Within the means, students' involvement is elemental in the development of learning. Students will be closely monitored in the learning processes if there is self-reflection on their engagement. If there is minimal involvement, only limited reflection is presented. The commitment in the process of learning involves thinking significantly. High engagement with more thought is ultimately preferable in the process of learning. It will be impeccable if a reflection is performed within the learning processes since the students are more aware of their learning progress (Di Stefano, Gino, Pisano, \& Staats, 2016). Reflecting on experiences with active engagement and thinking encourages insight and complex learning (Costa \& Kalick, 2008). Nevertheless, it is also crucial to ensure the learning tasks are adequately structured. Only well-structured learning tasks will encourage students to think and subsequently develop more thinking to happen with better engagement in learning.

Previous studies (such as Di Stefano et al., 2016) have argued that classroom learning can be more effective if coupled with reflection. In the representation, students have more space to recall their experiences in their knowledge and understand more about their intentional attempt to synthesize and evaluate lessons attended. The previous studies focused on students' perception of the means of reflection in activities. Elbers (2003) highlighted the importance of examining students' reflection on how they understand the tasks and their thinking in solving the tasks given. Nevertheless, students also show different attitudes such as beliefs and abilities, which psychologically will affect their thinking. Hence, it is crucial to look into how they reflect on their learning qualitatively. There is also a need to investigate students' learning attitude and cognitive development based on their written text in the reflection. The written reflection is part of the inputs for the qualitative data analysis. The analysis involves codification of students' experiences in the learning process. Commonly, experience is presented for the proper selected learning tasks. The selected tasks should be appropriately assigned so that students experience more cognitively (Elbers, 2003; Fosnot, 2005). Significantly, this study aims to examine the students' beliefs and abilities when they are engaging in problem-solving within a Mathematics classroom.

eISSN: 2398-4287 ( 2020. The Authors. Published for AMER ABRA cE-Bs by e-International Publishing House, Ltd., UK. This is an open access article under the CC BYNC-ND license (http://creativecommons.org/licenses/by-nc-nd/4.0/). Peer-review under responsibility of AMER (Association of Malaysian Environment-Behaviour Researchers), ABRA (Association of Behavioural Researchers on Asians) and cE-Bs (Centre for Environment-Behaviour Studies), Faculty of Architecture, Planning \& Surveying, Universiti Teknologi MARA, Malaysia.

DOI: https://doi.org/10.21834/ebpj.v5iSI1.2289 


\subsection{Literature Review}

Issues, difficulties and challenges students face are huge. Among the problems are students' achievement in learning mathematics. Students' low achievement in mathematics is always related to their failure in understanding the mathematical concepts. Schools may face difficulties to help the students if the students' level of prerequisite knowledge is not improving. Yet, they need to meet more challenging mathematical problems when they go to the next stage of learning. They may show attitudes of learned helplessness towards their study. Even though it is a heavy responsibility for schools to help and motivate the students, there are many guidelines such as Dweck's (1975) views have provided excellent examples for the development. Dweck (1975) highlighted that high emphasis on taking own responsibility and putting effort into any learning play significant roles for an individual performance. Hence, the students need to experience themselves in a mathematics classroom. Indeed, an excellent structured of activity and comprehensive learning contents create a comfortable environment for students to put effort and to be responsible of monitoring themselves in solving any severe mathematics problems (Teoh, Kor \& Shaminah Mustafa Kamalu, 2017). The students need more exposure primarily through doing, talking, reflecting, discussing, observing, investigating, listening and reasoning (Copley, 2000). Ideally, the students who engage in solving the problems are working on the learning tasks meaningfully. Meanwhile, the teacher can just occupy themselves to facilitate and activate students' prior knowledge through questioning to foster the development of habits of mind in thinking. The experience of being in such an environment of learning may develop students' interest and hence encourage the students to think about what works in solving the mathematical problems. There are many suggestions for designing meaningful activities to increase time students spend on a task and hence engage in learning. Lumsden (1994) emphasized that students are more engaged when they are given significant and worthy problems or course materials relate to real-life situations. Similarly, Parmjit and Teoh (2010) suggested that it is crucial to ensure content adequacy of school learning materials, namely the textbooks used in classroom activities. The excellent problem-solving contents serve as a crucial means before students can perform in problem-solving. On the other hand, students are enjoying their learning more when they are allowed to control over learning, such as having their strategies in solving problems (Brooks, Freiburger \& Grotheer, 1998). In completion of knowledge gained and sense of competency, the students also need to develop their connection of understanding. In such a case, students need to reflect their experience so that they can always recall their good practice and essential points as highlighted by Anderman \& Midgley (1998) and Copley (2000). They can reflect on their classroom learning activities. Indirectly, the students are more engaged and hence increase their time-on-task. The focus of time on task indicates the persistence in working through the challenges of solving any mathematics problems. The high engagement depicts many strategies used. Similarly, efforts made within written communication will further encourage students to think actively, especially when it involves discussions that require the students to make their best attempt while being engaged in their learning. Besides, the students need also to understand the process involved. Written reflection is beneficial at various levels and has become part of the teaching and learning process (Johns, 2000; Moon, 2013). It enables monitoring of individual experiences leading to a new understanding of the process of learning (Boud, Keogh \& Walker, 1985). Not only that, reflection becomes a form of response to the learners' experiences of their involvement in learning which enables students to get into the habit of linking and constructing meaning from their experiences (Feuerstein, Rand, Hoffman, \& Miller, 1980).

\subsection{Methodology}

This study employed a case research design. Hundred and twenty diploma students participated in this study. The students came from a university in Malaysia. A classroom learning in this case study has specific setting. The classroom setting is designed specifically to conduct the Mathematics lessons for the students in their first semester. The Mathematics lessons were conducted as a compulsory course for the students to further their studies. The contents of the Mathematics lessons include Mathematical problem solving, which required the use of Mathematical thinking skills. The students engaged in activities as well as solving word problem in Mathematics activities. They were taught the skills to solve Mathematics problems regarding algebra, geometry and statistics for each of the lessons. Then, they were given problems or activities to be solved. Later, they need to reflect on the classroom activities or discussions concerning the course. The duration of this case study is five weeks. Hence, the study employed a qualitative descriptive research design for a case study. Data were collected through the employment of reflective journal. The case study was designed to collect data using reflective writing. The students were required to reflect on the activities done in the classrooms. Mathematical problems written by Parmjit (2009) were administered in the activities. Among the activities, the students solved the following mathematical problem: If it takes six men to paint a house in 21 days, how many men will be needed to paint the house in 14 days? The reflective journal explored the students' learning for the five lessons presented. The students submitted their reflective journals immediately after each activity or lesson in the classroom through an online feedback system. The responses are based on the following discussions, as demonstrated in Table 1. The students' feedbacks in the reflective journal were analyzed based on the contents, as stated in Table 1. All the responses were assigned an appropriate code. The responses with similar code were categorized in one theme. There are a few themes for each of the questions as put in Table 1. Students' responses in scripts for each item were further presented to support the justification of the findings. The texts are indicated and labelled as R1 for the first respondent, R2 for the second respondent and the rest will follow suit the label.

\subsection{Results and Discussion}

The students have difficulties in understanding word problems, although they give their best efforts and engagement in thinking. The following (Table 1) are summaries of the five reflections. 
Table 1: Questions referred for the reflection

\begin{tabular}{cl}
\hline Week & \\
\hline 1 & Are the problems similar to the ones in your previous school examination? Why? Were the problems \\
& easy? \\
3 & Did you know how to solve the problems as you glance through them? Please explain \\
4 & Did the problems motivate you to search for a solution? Why? \\
5 & What are the common strategies you use in seeking the solution for the given problems? \\
\hline
\end{tabular}

\subsection{Results for reflection one}

Reflection One: The students reflected to the following question:

Are the problems similar to the ones in your previous school examination? Why? Were the problems easy?

Reflection One for the first lesson attempts to investigate students' perceptions towards the learning contents in the course. A few codes have been assigned based on the students' responses. The coding included 'Yes', indicating that the students agree that they had similar experiences in answering the questions and responding to the activities when they were in secondary school, while 'No' indicates the opposite, and 'sometimes' indicates their experiences were minimal.

\begin{tabular}{l|c|c}
\multicolumn{3}{c}{ Table 2 Feedback on the 1st reflection } \\
\hline Categories of response & Number of students & Percentage of students \\
\hline Yes & 34 & 28 \\
\hline No & 41 & 35 \\
\hline Sometimes & 28 & 23 \\
\hline No Response & 17 & 14 \\
\hline TOTAL & 120 & 100 \\
\hline
\end{tabular}

Table 2 shows that $14 \%$ of the respondents did not provide any reply. Meanwhile, only $86 \%$ of respondents replied. Hence, the results for the first question were reported based on a total of $35 \%$ of the students who have no experience in solving Mathematical problems which have been presented in the classroom learning. They found that the questions given were different from the questions they encountered in their secondary school years. Also, there are $51 \%(28 \%$ and $23 \%)$ of the students responded that they had managed similar types of questions from their secondary school years. The results show that the majority of the students agreed that the questions or problems are not new to them. They just need to apply some skills based on the related Mathematics concepts. These reflections have provided information on the students' belief that the Mathematics contents are interrelated. Even though some problems were new to the students, the questions were closely related to the secondary school Mathematics contents. Students must be exposed to many different types of problems for specific learning content. The teaching and learning of Mathematics should always be related to problemsolving. Thus, it is crucial to cultivate students to answer as many problems as possible while they are trying to understand any specific Mathematical concepts. In this situation, they have more chance to strengthen their understanding of any concepts in Mathematics. It is seen that the teaching and learning of mathematical concepts and skills need to include many different tasks, so that the students are displayed and challenged with various structured problems (Wood \& Sellars, 1996; Wood \& Sellars, 1997).

\subsection{Results for reflection two}

Reflection Two: The students reflected to the following question:

Did you know how to solve the problems as you glance through them? Please explain.

Table 3 shows that the majority of the students $(30 \%)$ responded that they need time to think for their understanding when they read the questions.

Table 3 Feedback on the $2^{\text {nd }}$ reflection

\begin{tabular}{|c|c|c|}
\hline Categories of response & Number of students & Percentage of students \\
\hline Difficult & 18 & 15 \\
\hline Engage thinking & 36 & 30 \\
\hline Good experience & 2 & 2 \\
\hline Guidance & 27 & 23 \\
\hline Need more exposure & 1 & 1 \\
\hline Time spent & 20 & 16 \\
\hline No response & 16 & 13 \\
\hline TOTAL & 120 & $100 /$ \\
\hline
\end{tabular}

The students provided some reasons for their difficulty to answer the question smoothly. For instance, the students claimed that they needed some guidance, or they needed more time to answer the questions. The respondents provided the following response (from R7): "For the second week, I think it's getting a little bit easier for me to solve the problems. But I still need some more practice and guidance to solve the problems given. It's because I can't solve it just by a single glance and need some extreme brainstorming to find the solution. I hope I will get better from time to time and get to use it as fast as I can". The findings indicate that the students need guidance which mostly comes from teachers and discussion with their friends. This kind of cooperative learning is encouraged in the 
Mathematics classroom, as highlighted by Johnson \& Johnson (1975) and Davidson (1990). Students who provide reasons in answering questions are considered as active thinkers. With reasoning, they will be able to discuss with others (Copley, 2000) while they still need some kind of guidance from their teachers (Ma, 1999; Stigler, 2004; Weiss, Heck \& Shimkus, 2004).

\subsection{Results for reflection three}

Reflection Three: The students reflected to the following question:

Did the problems motivate you to search for a solution? Why?

Table 4 shows that a total of $67 \%$ responded to Reflection Three. There were $33 \%$ of respondents did not provide inputs to the reflection.

Table 4 Feedback on the $3^{\text {rd }}$ reflection

\begin{tabular}{|c|c|c|}
\hline Categories of response & Number of students & Percentage of students \\
\hline Difficult & 2 & 2 \\
\hline Effort & 41 & 34 \\
\hline Interested & 20 & 16 \\
\hline Think & 18 & 15 \\
\hline No response & 39 & 33 \\
\hline TOTAL & 120 & 100 \\
\hline
\end{tabular}

When they were asked whether the questions motivated them to search for the solutions, majority of the respondents (as shown in Table 4) provided their feedback that the questions drive them to find for answers with the justification that they had put a lot of 'effort' $(34 \%)$. On a more positive essence, they found that the questions are interesting. The students were 'interested' (16\%) to answer the questions and that the questions motivate them to 'think' $(15 \%)$. Only $2 \%$ of the respondents found that they were not motivated to solve the problems since the problems were too severe for them. Generally, the questions have prompted them to have more effort to solve Mathematical problems. Initiatives that the students put in to solve the problems have impressively encouraged them to think more for the understanding of the problems. The development of thinking is always related to students' communication skills, such as asking more questions for clarification. Their communication skill is primarily essential for them since communication within the text and interaction between students and teacher as well as between students and students could prompt deeper thinking (Reinhart, 2000). Cognitively, they were taking their responsibilities to understand and monitoring themselves. Hence, they gave more attention in their own learning by putting effort and thinking more (Zimmerman \& Schunk, 1989).

\subsection{Results for reflection four}

Reflection Four: The students reflected to the following question:

What are the common strategies you use in seeking the solution for the given problems?

Table 5 shows that a total of $86 \%$ responded to Reflection Four. There were $14 \%$ of respondents did not provide inputs to the reflection.

Table 5 Feedback on the $4^{\text {th }}$ reflection

\begin{tabular}{l|c|c}
\hline Categories of response & Number of students & Percentage of students \\
\hline Discuss & 9 & 8 \\
\hline Experience & 18 & 15 \\
\hline Formula & 11 & 9 \\
\hline Pattern & 17 & 14 \\
\hline Process & 7 & 6 \\
\hline Understanding & 33 & 27 \\
\hline Visual & 8 & 7 \\
\hline No response TOTAL & 17 & 14 \\
\hline & 120 & 100 \\
\hline
\end{tabular}

When the students reflected to this question, they recalled the strategies used in solving the questions. As stated by Schoenfeld (1985), carrying appropriate strategies can help students to develop their thinking skills. The result is presented in Table 5 . The table shows that majority of the students (27\%) first step in attempting mathematical problem solving is first to understand the task given. This result suggested that the students took the time to read the questions carefully and with some action to comprehend the problems given $(27 \%)$ such as to read the question a few times, interpret or set into the different context or compare to other previous question solutions. In this study, the respondents (15\%) agreed that they depended on their prior knowledge and learned to use different strategies to solve problems. Alternatively, another approach that the students took was looking at patterns in solving problems (14\%). Other than that, they $(9 \%)$ have the preference to use formula, and visualization $(7 \%)$. The students were also in favour to discuss (8\%) and they were not successful in handling all the process of solving problems. Only $6 \%$ of the students managed to apply the complete strategies of problem-solving, namely; understand the problems, plan a strategy, implement the strategy and recheck. The processes or strategies of problem solving are interpreted in Polya's (1960) teaching and learning of problem-solving.

\subsection{Results for reflection five}

Reflection Five: The students reflected to the following question: 
What challenges did you face in this course? Please explain.

Table 6 shows that a total of $80 \%$ responded to Reflection Five. There were $20 \%$ of respondents did not provide inputs to the reflection.

Table 6 Feedback on the $5^{\text {th }}$ reflection

\begin{tabular}{l|c|c}
\hline Categories of response & Number of students & Percentage of students \\
\hline Collaboration & 4 & 3 \\
\hline Difficult & 85 & 71 \\
\hline Interesting & 7 & 6 \\
\hline No response TOTAL & 24 & 20 \\
\hline \multicolumn{2}{r}{} \\
\hline
\end{tabular}

The types of challenges that the students experienced is shown in Table 6 . A majority of $71 \%$ of respondents described that they have problems in solving the questions since they were challenging. Only $6 \%$ of the students found that it is interesting even though it is difficult and $3 \%$ of the students needed collaboration in solving the questions after they had gone through the 5-week lessons. The results also revealed that the majority of the students found the tasks given were difficult. Regardless, it is much delighted to identify that the students put their best efforts into solving the problems while wholeheartedly attempted to understand the problems.

\subsection{Conclusion}

The students found that the tasks were challenging. They also indicated that they need more time to understand and communicate within the text. Their response echoes the tasks that they were solving are in high-level. Explicitly, high-level tasks are often complex and more time is required for the problem solvers to think as described by Doyle $(1983,1986,1988)$. About their knowledge of solving the mathematical problems, they expressed that they were unable to solve the questions quickly. They found that they engaged themselves in thinking $(30 \%)$ and they needed more guidance $(23 \%)$, and they were willing to spend time dealing with the problems $(16 \%)$. The results reflect that the mathematical tasks are appropriately constructed. The tasks had engaged students in thinking. The tasks can be used to develop students' mathematical thinking since the roles of mathematical tasks to engage students were shown in this study. The importance of constructing mathematical tasks which enable the development of thinking and reasoning is also highlighted by Heibert \& Wearne (1993) and Stein, Smith, Henningsen \& Silver (2000). On the other hand, even though the students were facing difficulties to understand the questions, the majority of them were motivated to engage themselves for further solving of the questions.

As a conclusion, the reflection in this study had provided related information about the students' learning of mathematics in a mathematics classroom. This study discovered that the students have experience in solving the mathematical problem since they had seen similar types of question. Still, they found that problem-solving in mathematics is very challenging to them. They responded that the questions were difficult. Nevertheless, it was their practice that they put in the effort to understand the questions and the majority of the students need more time to think and hence engage in solving the problems. Thus, this study suggested that it is crucial to engage students in a classroom activity to develop their mathematical thinking skills.

\section{Acknowledgments}

This study is part of a larger study and the authors gratefully acknowledge the funding by the Research Interest Groups (RIG) Grant from Universiti Teknologi MARA, Malaysia. Grant: 600-RMI/DANA 5/3/REI(17/2015) MATHEMATICAL THINKING FOR TEACHING RESEARCH GROUP.

\section{References}

Anderman, L.H., \& Midgley, C. (1998). Motivation and middle school students [ERIC digest]. Champaign, IL: ERIC Clearing-house on Elementary and Early Childhood Education. (ERIC Document Reproduction Service No. ED 421 281)

Boud D. Keogh R. Walker D. (1985) Reflection: Turning experience into learning. Kogan Page, London.

Brooks, S.R., Freiburger, S.M., \& Grotheer, D.R. (1998). Improving elementary student engagement in the learning process through integrated thematic instruction Unpublished master's thesis Saint Xavier University, Chicago, IL. (ERIC Document Reproduc- tion Service No. ED 421 274)

Costa, A.L., \& Kalick, B. (2008). Learning through reflection. In Arthur L. Costa and Bena Kallick (Eds). Learning and leading with habits of mind: 16 essential characteristics for success. Chapter 12. The Association for Supervision and Curriculum Development (ASCD).

Copley, J.V. (2000). The young child and mathematics. Washington, DC: National Association for the Education of Young Children.

Davidson, N. (Ed.). (1990). Cooperative learning in mathematics: A handbook for teachers. Menlo Park, CA: Addison-Wesley.

Di Stefano, G., Gino, F., Pisano, G.P. and Staats, B.R., (2016). Making Experience Count: The Role of Reflection in Individual Learning. Harvard Business School NOM Unit Working Paper No. 14-093; Retrieved July 2, 2017 at https://ssrn.com/abstract=2414478 or http://dx.doi.org/10.2139/ssrn.2414478 
Doyle, W. (1983). Academic work. Review of Educational Research, 53(2), 159-199.

Doyle, W. (1986). Classroom organization and management. In M. C. Wittrock (Ed.), Handbook of research on teaching (3rd ed.; pp. 392-431). New York: Macmillan.

Doyle, W. (1988). Work in mathematics classes: The context of students' thinking during instruction. Educational Psychologist, 23, 167-180. G

Dweck, C. (1975). The role of expectations and attributes in the alleviation of learned helplessness. Journal of Personality and Social Psychology, $31,674-685$.

Elbers, E (2003). Classroom interaction as reflection learning and teaching mathematics in a community of inquiry. Educational Studies in Mathematics 54: 77-99, 2003

Feuerstein, R., Rand, Y., \& Hoffman, M., \& Miller, R. (1980). Instrumental Enrichment: An intervention program for cognitive modifiability. Baltimore, MD: University Park Press.

Fosnot, C.T. (2005). Constructivism revisited: Implications and reflections. The Constructivist, 16(1).

Heibert, J., \& Wearne, D. (1993). Instructional tasks, classroom discourse, and students' learning in second-grade arithmetic. American Educational Research Journal, $30,393-425$

Johns C (2000). Becoming a reflective practitioner. Blackwell Science, Oxford.

Johnson, D., \& Johnson, R. (1975). Learning together and alone: Cooperation, competition, and individualization. Englewood Cliffs, NJ: Prentice Hall.

Lumsden, L.S. (1994). Student motivation to learn (ERIC Digest No. 92). Eugene, OR: ERIC Clearinghouse on Educational Management. (ERIC Document Reproduction Service No. ED 370 200)

Ma, L. (1999). Knowing and Teaching Mathematics: Teachers' Understanding of Fundamental Mathematics in China and the United States. Mahwah, N.J.: Lawrence Erlbaum

Moon, J. A. (2013). Reflection in learning and professional development: Theory and practice. London: Kogan Page.

Parmjit, S. (2009). Mathematical Problem Solving for Teenagers. Primera Publication.

Parmjit, S., \& Teoh, S.H. (2010). An analysis of addition and subtraction word problems in mathematics textbook used in Malaysia primary school classroom. Brunei Int.J.of Sci.\& Math. Edu., 2(1), 68-85.

Polya, G. (1962). Mathematical discovery: On understanding, learning and teaching problem solving: Volume I. New York: John Wiley and Sons, Inc.

Reinhart, S.C. (2000). Never say anything a kid can say. Mathematics Teaching in the Middle School, 5 (8).

Schoenfeld, A. H. (1985). Mathematical problem solving. Orlando, FL: Academic Press.

Stein, M. K., Smith, M. S., Henningsen, M. A., \& Silver, E. A. (2000). Implementing standard-based mathematics instruction. NY: Teacher College Press, Columbia University.

Stigler, J. (2004). The Teaching Gap: Reflections on Mathematics Teaching and How to Improve It. Paper presented at the Pearson National Educational Leadership Conference, Washington, D.C., March 2004.

Teoh, S.H., Kor, L.K., \& Shaminah Mustafa Kamalu (2017). Self-management strategies in a student-driven learning environment. In Nor Aziah Alias and Johan Eddy Luaran (Eds). Student-Driven Learning Strategies for the 21st Century Classroom 62-71.

Weiss, I.R., Heck, D.J., \& Shimkus, E.S. (2004) Mathematics Teaching in the United States. Journal of Mathematics Education Leadership, 7, 23-3

Wood, T; Sellers, P. (1996). Assessment of a problem-centered mathematics program: 3rd grade. Journal for research in mathematics education (Reston, VA), vol. 27, p. 337-53.

Wood, T; Sellers, P. 1997. Deepening the analysis: longitudinal assessment of a problem- centered mathematics program. Journal for Research in Mathematics Education (Reston, VA), vol. 28, p. 163-86.

Zimmerman, B., \& Schunk, D (Eds) (1989). Self-regulated learning and academic achievement: Theory, research and practice. New York: Springer. 